\title{
Gambaran Coping Strategy pada Remaja Puteri yang Melakukan Pernikahan Dini
}

\author{
Fia Oktaviani, Nani Nuranisah Djamal, \& Imam Sunardi \\ Fakultas Psikologi UIN Sunan Gunung Djati Bandung Jl. A.H Nasution No. 105 Bandung \\ e-mail: fiaoktapsy@gmail.com
}

\begin{abstract}
The adolescents usually spent time as a student. However, there were adolescents who married early which may cause them to lose one of the most important duties in their adolescences period, such as preparing for marriage and household. Adolescents who married in early age have a new role in their life as an adult. Marriage life came with its own problems that may cause stressors. Stressors can be solved by individual's coping strategies. Coping is the way individual deal with stressful situation. The purpose of this study was to explore the coping used by married adolescents at the age of 15-16 years old in Bandung. This study used qualitative method and phenomenology research with three key informants. The results of this study show that three subjects used emotion-focused coping more dominant than problem-focused coping. The reason was the subjects mostly use feeling and show emotional signs when they have problems.
\end{abstract}

Keywords: coping strategy, early marriage, adolescents

\begin{abstract}
Abstrak
Masa remaja umumnya menghabiskan waktu dengan bersekolah namun adanya remaja yang memutuskan untuk menikah dini menyebabkan kehilangan salah satu tugas penting dalam fase perkembangannya yakni mempersiapkan perkawinan dan rumah tangga. Remaja yang menikah memiliki peran baru sebagai seorang dewasa, adanya permasalahan dalam pernikahan menimbulkan tekanan yang dapat diselesaikan dengan cara koping yaitu upaya yang dilakukan individu untuk menghadapi situasi menekan. Penelitian ini bertujuan untuk mengetahui upaya penyelesaian koping yang dilakukan oleh ketiga subyek yang menikah di usia 15-16 tahun di Bandung. Penelitian ini menggunakan metode kualitatif dengan pendekatan fenomenologi yang melibatkan tiga remaja puteri sebagai subyek penelitian. Hasil penelitian menunjukkan ketiga subyek menggunakan kedua koping dalam penyelesaiannya namun lebih cenderung menggunakan koping penyelesaian fokus emosi dibandingkan fokus masalah, hal ini disebabkan karena ketiga subyek lebih banyak menggunakan perasaan dan menunjukkan tanda emosional saat menghadapi masalah.
\end{abstract}

Kata Kunci: coping strategy, pernikahan dini, remaja

\section{Pendahuluan}

Remaja didefinisikan sebagai masa peralihan antara masa anak-anak dan masa dewasa yang berjalan antara umur 12 sampai 21 tahun (Papalia, Olds, \& Feldman, 2008). Umumnya remaja menghabiskan waktu dengan bersekolah, pencarian identitas dan mengembangkan diri. Hal ini berdampak pada kesiapan mental emosional, kemantapan pengambilan keputusan, dan perencanaan masa depan (Desmita, 2005). Ada beberapa persoalan yang terjadi pada remaja. Salah satunya persoalan sosial yang hingga saat ini menjadi masalah kompleks yaitu banyaknya remaja yang memutuskan menikah di usia belasan tahun atau disebut pernikahan dini.

Dalam Undang-Undang Perkawinan, lelaki diperbolehkan menikah jika usianya 19 tahun dan perempuan 18 tahun. PerundangUndangan Kesehatan No. 36 tahun 2009 memperbolehkan menikah jika usianya di atas 20 tahun. Apabila merujuk pada psikologi perkembangan hal ini bertentangan dengan tugas perkembangan remaja yang semestinya. Sebab menikah dini akan mengurangi persiapan perkawinan. Selain itu akan menimbulkan permasalahan dalam mempersiapkan tugas serta tanggung jawab dalam kehidupan berkeluarga. Menurut Casmini (2002) dari segi 
psikologis, usia terbaik menikah yaitu 20-25 tahun.

Selain itu pernikahan dini dalam psikologi perkembangan, Hurlock (1994) mengatakan bahwa pernikahan di bawah usia 20 tahun merupakan usia belum matang dan belum siap untuk berumah tangga, mereka masih berada di bawah perlindungan orangtua.

Menurut data terakhir Survei Demografi dan Kesehatan Indonesia (SDKI) tahun 2017 menunjukkan $12.8 \%$ perempuan usia 15-19 tahun sudah menikah. Bahkan saat ini Indonesia menempati peringkat ke-37 dengan persentase tertinggi di dunia dan peringkat kedua tertinggi di Asia Tenggara setelah Kamboja. Di Jawa Barat sendiri, khususnya Kabupaten Bandung masih menyumbang angka dalam persoalan pernikahan dini.

Menurut Papalia, Olds, dan Feldman (2008) usia merupakan prediktor utama dalam perkawinan karena dapat menentukan lamanya suatu hubungan. Bruce (2007) mengatakan tingginya angka perceraian disebabkan oleh banyaknya remaja menikah dengan tidak mempertimbangkan usia. Menikah dini merupakan satu beban psikis karena dalam menjaga keharmonisan rumah tangga memerlukan kedewasaan dalam berpikir dan bertindak. Sesuai dengan hasil riset penelitian Tydar (2012) tentang pernikahan dini di Desa Legoksari, Temanggung yang dilakukan oleh remaja dimana belum bisa mengontrol emosi dengan baik sehingga seringkali memicu terjadinya konflik, salah satunya perceraian. Maka dari itu usia penting dipertimbangkan untuk keperluan kesiapan mental dalam menghadapi permasalahan saat menjalani kehidupan berumah tangga.

Pernikahan dini berpengaruh pada perkembangan biologis dan psikologis. Menurut Papalia, Olds, dan Feldman (2008) secara biologis, kematangan reproduksi remaja akhir berada di usia 22 tahun, sehingga menikah dini rentan terjadinya infeksi. Secara psikologis, emosi remaja masih dalam tahap perkembangan sehingga pernikahan pada remaja akan membentuk kepribadian yang belum matang dan menyebabkan terjadinya pertengkaran karena emosi yang tidak terkontrol.

Khairunnisa dan Setiali (2016) mengatakan remaja yang menikah rentan akan stres terutama saat menjalani peran baru sebagai orangtua muda. Hal tersebut dikarenakan remaja belum bisa mengelola stres dan mengendalikan emosi secara menyeluruh. Sehingga dampaknya pada remaja yang menikah belum bisa menyesuaikan diri dengan baik.

Menurut Sears, Freedman dan Peplau (1994) menyatakan bahwa terjadinya persoalan pada pasangan yang sudah menikah karena adanya penyatuan dua pribadi yang unik. Dalam psikologi keluarga (Ulfiah, 2016, h. 81) ada beberapa permasalahan yang umumnya terjadi setelah menikah diantaranya masalah komunikasi, konflik orang tua-anak, cemburu, ekonomi, merasa superior, perselingkuhan, campur tangan orang tua dan kekerasan dalam rumah tangga.

Kemudian data terakhir sepanjang tahun 2010-2017, Pusat Pelayanan Terpadu Perlindungan Perempuan dan Anak (P2TP2A) Jawa Barat telah menangani 1.249 kasus mulai dari kekerasan rumah tangga hingga human trafficking. Selain itu persoalan yang berujung perceraian banyak terjadi pada pernikahan dini. Menurut Kemenag (2016), jumlah perceraian terbanyak terjadi di Jawa Barat dengan 33.684 kasus dan didominasi oleh perceraian keluarga muda sebanyak $80 \%$ yang baru menikah selama 2-5 tahun.

Kemudian Raharjo, Puspitawati, dan Krisnatuti (2015, h. 39) mengungkapkan bahwa persoalan utama setelah menikah yakni tekanan ekonomi. Hal ini terjadi karena ketidakberfungsian keluarga muda dimana suami tidak dapat memenuhi kebutuhan dan berdampak stress, pertengkaran rumah tangga hingga penyebab KDRT. Dariyo (2004, h. 95) mengatakan kesejahteraan keluarga dimulai dari fondasi dasar untuk dapat memenuhi kebutuhan keluarga yang dapat dicapai melalui kondisi ekonomi yang baik.

Umumnya permasalahan dalam rumah tangga banyak dialami oleh perempuan karena lebih menggunakan perasaan dan menunjukkan tanda emosional saat menghadapi masalah seperti lebih sering merasa cemas, takut, bingung, berkecil hati dan stress. Perempuan lebih menggunakan perasaan yang didorong oleh afek dan sentiment kuat sehingga mudah membuat dugaan keliru yang menimbulkan konflik bagi dirinya sendiri. Hal ini juga terjadi karena usia serta emosi remaja yang belum stabil berdampak pada kemampuan yang belum matang dalam menyelesaikan konflik (Kartono, 2002). 
Selain itu, Dewi dan Basti (2008, h. 50) mengungkapkan sudut pandang perempuan dalam memecahkan persoalan selalu meng-ikut sertakan perasaan dan suasana hati sehingga cepat mengambil tindakan atas dasar emosi. Selain itu perempuan selalu ingin mendapat perhatian dan melakukan pengaduan untuk mendapat ketenangan.

Sekitar 22.000 perempuan di bawah usia 15 tahun terikat pernikahan dan hasil survei demografi menunjukkan $10 \%$ remaja usia 15 19 tahun sudah melahirkan anak pertama (Kementerian Kesehatan, 2013). Selain itu, perempuan yang menikah sebelum usia 18 tahun tercatat sebesar 23\% (Priherdityo, 2016). Data -data di atas menunjukkan bahwa hingga saat ini angka pernikahan dini di Indonesia terbilang cukup tinggi.

Setelah dilakukan pengamatan di wilayah Kabupaten Bandung selatan, fenomena pernikahan dini masih terjadi di beberapa daerah sehingga kondisi geografis dapat berpengaruh terhadap jumlah pernikahan dini.

Menurut Kepala Desa ada beberapa hal yang mendukung terjadinya pernikahan dini di Desa Sukapura. Pertama, rendahnya tingkat ekonomi sehingga orangtua menikahkan anaknya karena tidak mampu membiayai sekolah ke jenjang selanjutnya. Kedua, mayoritas penduduk menjadi buruh tani, para orangtua pun mendidik anaknya agar bertani sehingga dukungan untuk bersekolah kurang dan rendahnya motivasi. Ketiga, rendahnya tingkat pendidikan, mayoritas penduduk dengan lulusan SD dan SMP mendukung pernikahan dini. Selain itu banyak yang tidak tamat bersekolah sehingga keputusan yang diambil adalah menikah. Keempat, sosial budaya, adanya peranan kuat untuk menikah dini dan orangtua yang ikut menentukan kehidupan pernikahan anaknya (komunikasi personal, 03 April 2017).

Kemudian menurut ketua RW di Dusun Argasari mengatakan penduduknya banyak termasuk golongan pra-keluarga sejahtera didominasi oleh pernikahan dini. Banyak orangtua dari remaja belasan tahun mengajukan persyaratan menikah tanpa memiliki KTP bahkan tidak sedikit yang pernikahannya tidak bertahan lama dan berujung perceraian (komunikasi personal, 05 April 2017).

Berdasarkan hasil wawancara dengan tiga informan yang telah menikah beserta significant other. Informan pertama (R) menikah di usia 16 tahun dengan lelaki lebih tua 6 tahun karena sudah tidak tahan menjadi bahan pembicaraan sekitar, di lingkungannya perempuan yang belum menikah di usia 15-17 tahun dianggap tidak laku padahal dirinya masih ingin bersekolah namun terhambat biaya. Saat ini usia pernikahannya berjalan 6 tahun dan telah dikaruniai seorang anak berusia 3 tahun. Persoalan yang dialami setelah menikah diantaranya kebutuhan ekonomi, perasaan cemburu, curiga, merasa tidak adil, merasa dibohongi. $\mathrm{R}$ mengatakan pernah menghadapi persoalan sulit di awal pernikahan yang hampir bercerai karena perbedaan pendapat (komunikasi personal, 07 April 2017).

Menurut Ibu R, pernikahan dini sudah biasa. Beliau merasa malu saat anaknya menjadi bahan pembicaraan tetangga sekitar karena belum menikah sedangkan temantemannya sudah banyak yang menikah di usia 14 tahun. Beliau langsung setuju saat ada lelaki yang mengajak anaknya menikah, karena saat itu tidak mampu menyekolahkan $\mathrm{R}$ maka beliau langsung menikahkan anaknya (komunikasi personal, 07 April 2017).

Informan kedua (S) menikah di usia 15 tahun dengan lelaki lebih tua 5 tahun karena melihat teman-temannyasudah menikah di usia 14 tahun. Saat ini usia pernikahannya berjalan 10 tahun, telah dikaruniai seorang anak lakilaki berusia 8 tahun dan sedang mengandung anak kedua berusia 4 bulan. Persoalan yang dialami seperti salah paham, kebutuhan ekonomi, dan tanggung jawab (komunikasi personal, 09 April 2017).

Menurut Ibu S, beliau menikahkan anaknya karena melihat sikap S yang dianggapnya dewasa sudah bisa melakukan pekerjaan rumah tangga juga melihat teman-teman di sekitarnya sudah menikah. Pernikahan dini sudah hal yang lumrah, melihat hubungan $\mathrm{S}$ dengan pacarnya saat itu sama-sama saling mencintai jadi segera dinikahkan agar menghindari perzinahan juga menghindari pembicaraan tetangga (komunikasi personal, 09 April 2017).

Informan ketiga (C) menikah di usia 15 tahun dengan lelaki berusia 26 tahun karena adanya desakan dari orangtua. Pernikahannya berjalan selama satu setengah tahun, selama menikah dirinya merasa tidak nyaman dan tertekan karena tidak mencintai suaminya sehingga terbebani. Setelah menikah dirinya sering merasa kesal karena suaminya tidak 
bertanggung jawab, malas bekerja sehingga tidak dinafkahi dan kebutuhan ekonomi pun tidak terpenuhi. Pada akhirnya $\mathrm{C}$ mengeluh pada orangtua nya yakni di usia pernikahan 2 tahun dan memutuskan untuk bercerai dengan suami di usianya 17 tahun (komunikasi personal, 11 April 2017).

Menurut Ibu C, saat itu anaknya baru lulus SMP sempat tidak mau untuk dinikahkan namun ayah tirinya merasa tidak nyaman karena lelaki yang menyukai $\mathrm{C}$ selalu baik dan datang setiap hari ke rumahnya. Beliau takut anaknya menjadi bahan pembicaraan warga maka dari itu beliau segera menikahkan anaknya (komunikasi personal, 11 April 2017).

Dari ketiga informan beserta significant others di atas dapat disimpulkan bahwa berbagai permasalahan yang dialami setelah menikah didominasi oleh masalah internal atauemosionalitas. Untuk menghadapinya maka diperlukan coping strategy yakni adanya usaha atau penyelesaian yang dilakukan individu dalam menghadapi situasi yang menekan.

Meneliti berbagai permasalahan serta upaya penyelesaiannya pada remaja puteri yang menikah dinilai sangatlah penting karena sejumlah alasan. Adanya kesenjangan antara teori dan fakta di lapangan, usia dan emosi yang belum matang, tidak adanya pengalaman serta ketidaksiapan dalam fisik maupun psikis menjadi landasan pada penelitian ini. Oleh karena itu peneliti tertarik untuk melakukan penelitian terhadap fenomena tersebut.

\section{Remaja}

Menurut Golinko (1984, dalam Rice, 1990) kata "remaja" berasal dari bahasa latin yaitu adolescence yang berarti to grow maturity. Masa remaja adalah masa transisi perkembangan antara masa anak-anak dan dewasa yang umumnya dimulai pada usia 1213 tahun dan berakhir pada usia awal dua puluhan. Papalia, Olds, \& Feldman (2008) remaja adalah sebagian perkembangan masa kanak-kanak masih dialami namun sebagian kematangan masa dewasa sudah dicapai. Menurut Santrock (2007) remaja adalah periode transisi perkembangan antara masa kanak-kanak dengan masa dewasa yang melibatkan perubahan biologis, kognitif dan sosio-emosional.

Menurut Santrock (2007) lazimnya masa remaja dimulai sekitar usia 12 tahun dan berakhir pada usia 18 hingga 22 tahun.Menurut
Papalia \& Olds (2001, dalam Yahya, 2011, h. 231-234) terdapat empat aspek perkem-bangan remaja yaitu fisik, kognitif, emosi dan kepribadian sosial.

Kay (1998, dalam Yahya, 2011, h. 238) mengemukakan tugas perkembangan remaja yaitu (a) mampu menerima fisik dan memiliki kepercayaan akan kemampuannya sendiri; (b) mencapai kemandirian sosial dan kematangan emosional; (c) mengembangkan keterampilan komunikasi interpersonal; (d) identifikasi diri; (e) memperkuat self control; dan (f) mampu menyesuaikan diri. Menurut Yahya (2011, h. 235) terdapat empat perubahan yang terjadi pada remaja yaitu adanya peningkatan emosional karena perubahan hormone, adanya perubahan fisik secara eksternal dan internal, adanya peningkatan dalam bersosialisasi dan berkomunikasi dan perubahan nilai dimana pada masa ini akan mulai meninggalkan kebiasaan pada masa kanak-kanak.

\section{Pernikahan Dini}

Menurut Undang-Undang Perkawinan Republik Indonesia No. 1 Tahun 1974 Bab 7 Pasal 1 menyebutkan perkawinan adalah ikatan lahir batin antara pria dengan wanita sebagai suami istri dengan tujuan membentuk keluarga (rumah tangga) yang bahagia dan kekal berdasarkan Ketuhanan Yang Maha Esa (dalam Gilarso, 2003). Hasil revisi undang-undang perkawinan menyatakan usia minimum perkawinan bagi perempuan telah ditetapkan yakni dari 16 tahun menjadi 18 tahun dan lakilaki 19 tahun.

Menurut Casmini (2002, h. 50) dan Fadliyana (2009, h. 139) terdapat empat penyebab pernikahan dini yaitu: 1) konstruk budaya: adanya paksaan orangtua dan stigma sosial pada penduduk desa apabila perempuan yang telah pubertas dan belum menikah terkadang diberi julukan perawan tua; 2) kecelakaan: adanya remaja yang telah melakukan hubungan seksual di luar nikah; 3) emosionalitas : emosi remaja sangat labil yang berakibat kepada cepatnya pengambilan keputusan untuk menikah; 4) sosial dan ekonomi: orangtua segera menikahkan anaknya dalam usia remaja karena motif ekonomi yaitu harapan tercapainya keamanan sosial dan finansial anaknya.

Menurut Landung, Ridwan, dan Zulkifli (2009, h. 91) terdapat dua dampak pernikahan dini yaitu positif dan negatif. Dampak positif 
diantaranya (a) mendapat dukungan emosional, dapat melatih kecerdasan emosional dan spiritual dalam diri tiap pasangan; (b) dukungan keuangan, dengan menikah dini dapat meringankan beban ekonomi apabila remaja yang tidak lagi tinggal dengan orang tua; (c) belajar memikul tanggung jawab usia dini; dan (d) terbebas dari perbuatan zina. Sedangkan dampak negatif diantaranya (a) motivasi dan minat belajar berkurang sebab banyaknya tugas rumah tangga; (b) sulit mendapat pekerjaan karena tidak memenuhi sejumlah kriteria; (c) pada perempuan rentan terjadinya infeksi saluran reproduksi karena pada saat hamil muda sel reproduksi belum matang; (d) dapat mengurangi harmonisasi keluarga disebabkan emosi yang masih labil serta cara berpikir yang belum matang; dan (e) perempuan yang menikah usia dini rentan depresi yang akan berisiko terhadap keguguran, peningkatan tekanan darah, dan berat badan lahir rendah.

Dalam prinsip pandangan Islam, pernikahan dini tidak meempermasalahkan dari segi usia, pernikahan boleh dilakukan apabila remaja sudah mencapai umur baligh dengan tujuan untuk menghindari hal-hal yang tidak diinginkan seperti adanya zina. Islam mendorong hal-hal yang menjamin suksesnya sebuah pernikahan. Batasan usia untuk menikah dalam Islam yaitu ketika kedua pasangan sudah mencapai usia baligh, terlepas dari kesiapan dan kematangan dalam hal psikisnya. Yang diminta adalah terciptanya diantara kedua pasangan untuk saling menyayangi, memberi, menerima, berbagi rasa, serta saling menasihati agar kedua pasangan dapat menjalani bahtera rumah tangga dan sama-sama meningkatkan ketakwaan kepada Allah SWT.

Adapun hadits yang menerangkan tentang pernikahan dini yaitu dalam hadits riwayat Bukhori Muslim, Rasulullah SAW bersabda "Wahai para pemuda, barangsiapa yang telah mampu hendaknya kawin sebab kawin itu akan lebih menundukkan pandangan dan akan lebih menjaga kemaluan. Kalau belum mampu, hendaknya berpuasa sebab puasa akan menjadi perisai bagimu."

Menurut salah satu pendiri teori psikologi humanistik Abraham Maslow (2009, dalam Alwisol, 2014, h. 45) cinta dipandang sebagai proses aktualisasi diri. Dalam menemukan aktualisasi dirinya individu secara relatif berasumsi akan pernikahan serta mencapai taraf aktualisasi dirinya lebih cepat. Pernikahan akan mematangkan seseorang sekaligus memenuhi separuh dari kebutuhan psikologis yang nantinya mampu mencapai puncak kepribadian yang mengesankan. Kemudian menurut Erich Fromm (2009, dalam Alwisol, 2014) semakin berjalannya waktu individu akan merasa kesepian dan upaya mengurangi rasa kesepian yaitu dengan menyesuaikan diri bersama pasangan dimana penyesuaian diri bersama pasangan dapat dilakukan melalui pernikahan.

\section{Coping strategy}

Coping strategy berasal dari kata "cope" berarti lawan, mengatasi. Lazarus \& Folkman (1984, h. 141) koping digambarkan sebagai cara individu berinteraksi dengan stresor. Adapun tujuan dari coping strategy menurut Lazarus \& Folkman (1984, h. 149) yaitu: a) mengurangi kondisi stressfull lingkungan dan kesempatan maksimum dalam penyembuhan; b) sabar menghadapi kejadian negatif; c) memelihara self-image yang positif; d) memelihara keseimbangan emosi; dan e) melanjutkan hubungan yang menyenangkan dengan orang lain. Ada dua bentuk koping dari Lazarus dan Folkman (1984, h. 152) yang menunjukkan adanya strategi koping diantaranya penyelesaian fokus pada masalah dan penyelesaian fokus pada emosi. Penyelesaian fokus pada masalah diantaranya confrontative coping, yakni usaha untuk mengubah keadaan yang dianggap menekan dengan cara agresif, tingkat kemarahan cukup tinggi dan pengambilan resiko. Selain itu ada juga planful problem solving, yakni usaha memecahkan masalah dengan tenang, hati-hati dan pendekatan analisis.

Sedangkan penyelesaian fokus pada emosi diantaranya: self control (usaha meregulasi perasaan dan tindakan pada situasi yang menekan); distancing (reaksi melepaskan diri atau usaha melarikan diri dalam permasalahan serta menciptakan pandangan yang positif); positive reappraisal (usaha menciptakan pandangan positif dengan memusatkan pada pengembangan personal dan melibatkan hal-hal yang bersifat religious); accepting responsibility (usaha untuk mengetahui peran dirinya dalam permasalahan yang dihadapi dan mencoba untuk menempatkan segala sesuatu dengan sebagaimana mestinya); escape atau avoidance (reaksi berkhayal atau usaha 
menghindar dan melarikan diri dari permasalahan); dan seeking social support (usaha mencari dukungan dari pihak luar berupa informasi, bantuan nyata maupun dukungan emosional).

Kemudian menurut Lazarus dan Folkman (1984, h. 157), faktor yang mempengaruhi penggunaan koping yaitu kesehatan fisik, keyakinan positif, keterampilan memecahkan masalah, keterampilan sosial, dukungan sosial, dan materi.

Terdapat hubungan diantara penggunaan kedua koping. Individu yang hanya menyelesaikan masalah namun dengan korban perasaan dan individu yang berhasil meredakan tegangan emosinya namun tidak dapat menyelesaikan sumber masalahnya tidak dapat dikatakan efektif dalam strategi pemecahan. Untuk mencapai strategi koping yang efektif diperlukan penggunaan kedua koping tersebut (Lazarus \& Folkman, 1984, h. 150).

Selain itu Islam mengajarkan berbagai coping strategy antara lain: a) berserah diri dengan ketentuan Allah; b) menjalin hubungan ilahiyyah yang baik dengan Allah; c) berpikir positif dan meyakini bahwa manusia selalu mempunyai sumber daya yang kuat untuk mengelola stress saat mendapati masalah; d) melakukan perbuatan baik bagi diri sendiri dan orang lain; e) melakukan usaha untuk mengubah keadaan yang menyulitkan; dan (f) bertawakkal kepada Allah setelah berusaha sekuat tenaga menyelesaikan masalah. Maka dari itu tujuan dari penelitian ini adalah untuk mengetahui upaya coping strategy yang dilakukan oleh remaja puteri yang melakukan pernikahan dini.

\section{Metode Penelitian}

Penelitian ini menggunakan kualitatif dengan pendekatan fenomenologi untuk mendapatkan pemahaman dalam penggunaan upaya penyelesaian masalah yang dilakukan oleh remaja puteri yang telah menikah. Pendekatan fenomenologi dipilih untuk mempermudah dalam mengidentifikasi hakikat pengalaman ketiga subyek terhadap permasalahan yang dihadapi. Oleh karena itu fokus dalam penelitian ini adalah tentang memaknai gambaran strategi koping yang dilakukan oleh ketiga remaja puteri yang telah menikah dalam menyelesaikan masalahnya.
Subyek dalam penelitian ini dipilih berdasarkan pertimbangan peneliti guna mendapatkan pemahaman secara spesifik tentang masalah yang terjadi dan fenomena yang terkait dalam penelitian. Penelitian ini melibatkan tiga orang remaja puteri yang telah menikah di usia 15-16 tahun dengan usia pernikahan lebih dari setahun. Alasan pemilihan subyek karena remaja puteri lebih menggunakan perasaan dan menunjukkan tanda emosional saat menghadapi masalah seperti lebih sering merasa cemas, takut, bingung, berkecil hati dan stress. Selain itu lebih menggunakan perasaan yang didorong oleh afek dan sentiment kuat sehingga mudah membuat dugaan keliru yang menimbulkan konflik bagi dirinya sendiri, hal ini terjadi karena usia serta emosi remaja yang belum stabil berdampak pada kemampuan yang belum matang dalam menyelesaikan konflik.

Pengambilan data dilakukan peneliti dengan melakukan pendekatan terhadap subyek, observasi, dan wawancara guna untuk memperoleh gambaran data yang valid tentang keadaan lingkungan subyek. Wawancara semi terstruktur dilakukan sebanyak empat kali pertemuan tiap subyek dan satu kali pertemuan dengan tiap significant other. Bungin (2008) mengatakan dengan wawancara semi struktur peneliti mendapat informasi sedalam mungkin serta menggali apa yang tersembunyi dalam diri subyek. Proses wawancara dilakukan funelling yaitu mengajukan pertanyaan bersifat umum kemudian spesifik (Smith, et.al, 1995 dalam Poerwandari, 1998) dengan tujuan mendorong subyek membicarakan mengenai topik yang dimaksud tanpa merasa diarahkan. Kemudian wawancara dilakukan atas persetujuan subyek dengan menggunakan alat perekam selama wawancara hal ini menurut Sutanto (2013) bertujuan untuk meminimalisir kehilangan informasi.

Kemudian peneliti menganalisis data penelitian dengan beberapa langkah diantaranya: a) mempersiapkan data untuk dianalisis dengan membuat transkrip wawancara; b) membangun konsep umum dengan membaca keseluruhan data; c) melakukan koding pada percakapan yang relevan; d) melakukan interpretasi hasil koding ke dalam pembahasan dan tabel; dan e) merumuskan kesimpulan penelitian.

Selain itu peneliti menyajikan hasil penelitian dalam bentuk deskriptif naratif diawali dengan menjelaskan gambaran subyek yang 
mencakup identitas subyek hingga informasi yang berhubungan dengan fokus penelitian. Setelah itu, peneliti melaporkan hasil penelitian dan analisisnya dengan membuat intra subyek dan inter subyek, sesuai dengan Rahman (2016) bahwa penelitian yang bertujuan mendeskripsikan fenomena akan lebih baik mendeskripsikan hasilnya secara deskripsi.

Guritnaningsih dan Lucia (2009, h. 68) mengatakan bahwa analisis intra subyek digunakan peneliti untuk membuat uraian tentang setiap subyek penelitian mencakup identitas diri, konteks, observasi serta gambaran umum subyek, sedangkan analisis inter subyek digunakan peneliti untuk membandingkan tiap subyek penelitian untuk melihat konsistensi aspek yang diteliti dalam beberapa subyek. Dengan analisis tersebut maka peneliti akan mendapat hasil penelitiannya secara faktual, interpretatif dan reflektif.

\section{Hasil Penelitian dan Pembahasan}

\section{Subjek 1 (R)}

$\mathrm{R}$ adalah seorang remaja perempuan yang saat ini berusia 22 tahun. $\mathrm{R}$ dilahirkan di Bandung pada tanggal 25 Mei 1995. R merupakan anak satu-satunya dari pasangan Alm I dan Alm W.R menempuh pendidikan terakhirnya di bangku SMP pada tahun 2010. R tidak melanjutkan ke SMA karena keterbatasan biaya. Setahun kemudian R memilih untuk meng-akhiri masa lajangnya dan saat ini $\mathrm{R}$ telah menikah dan bekerja sebagai ibu rumah tangga.

R menikah pada tahun 2011 saat usianya menginjak 16 tahun. $\mathrm{R}$ memilih untuk menikah dengan seorang laki-laki yang lebih tua 6 tahun dibanding dirinya dan sudah bekerja sebagai buruh tani. Jarak tempat tinggal keduanya tidak begitu jauh masih dalam satu Kecamatan hanya tinggal di Desa yang berbeda. Perkenalan R dengan suaminya berawal dari media sosial pertemanan di facebook. Pada saat itu hanya sebatas perkenalan saja lewat handphone lalu berlanjut pertemuan intens selama 3 bulan dan akhirnya menikah. Kondisi di kampung halaman $\mathrm{R}$ masih memegang kuat peranan adat budaya yakni jika ada perempuan sudah lulus SD atau sudah berumur 16-20 tahun namun belum menikah maka oleh tetangga sekitar disebut tidak laku dan dianggap sebagai perawan tua.
Saat itu $\mathrm{R}$ seringkali menjadi bahan pembicaraan tetangga karena belum menikah padahal baru saja lulus dari SMP. Pada saat itu $\mathrm{R}$ belum berusia 17 tahun jadi belum memiliki kartu tanda penduduk (KTP) dan sama sekali belum diijinkan oleh pemerintah untuk menikah. Namun karena peranan adat yang kuat disertai dorongan dari orang tua maka dari itu pernikahan tetap dilangsungkan.

Setelah menikah, $\mathrm{R}$ dan suaminya belum memiliki rumah sendiri jadi keduanya memilih untuk tetap tinggal di rumah R. Selama seatap dengan orangtua $\mathrm{R}$ ada saja masalah yang menimpanya hingga hampir bercerai namun $\mathrm{R}$ dan suaminya memutuskan untuk tidak tinggal lagi bersama orangtuanya, keduanya membangun rumah sederhana disamping rumah orangtua $\mathrm{R}$.

Saat ini $\mathrm{R}$ sudah menjalani pernikahan dengan suaminya selama 6 tahun dan sudah dikaruniai satu anak perempuan yang lahir pada tahun 2014. R melahirkan secara normal di rumahnya dengan bantuan Bidan desa dan saat ini anaknya sudah berusia 3 tahun.

Setelah menikah $\mathrm{R}$ di hadapkan pada berbagai masalah yang memicu pertengkaran, rasa curiga, cemburu, kesal, menyesal, merasa tidak adil, merasa dibohongi, kesalah pahaman, perbedaan pendapat dengan ibu kandung, hubungan renggang dengan ibu mertua, masalah ekonomi, pekerjaan suami, pembagian peran dan masalah anak.

\section{Penyelesaian fokus emosi.}

Self control. R seringkali merasa kesal saat ada masalah, dirinya merasa sedih dan selalu memendam perasaan namun jika merasa sangat kesal dirinya memberanikan diri untuk mengutarakan pada suaminya. Namun cara yang dilakukannya dalam meregulasi dirinya yaitu dengan cara mengunci sendiri di dalam kamar sambil menangis dan disaat merasa hilang kesabaran, dirinya melampiaskan rasa kesal pada anaknya.

"Saya nggak banyak ngomong soalnya suami saya malah marah." (S1.EFC.B.3a).

"Banyaknya sih dipendem karena nggak berani kalau ngomong langsung." (S1.EFC.B.3c).

"Ah saya kalau lagi kesel banget suka ngomong langsung ke suami." (S1.EFC.B.2c). 
"Kalau lagi ada masalah suka ngunci diri sambil nangis di rumah, nggak mau keganggu." (S1.EFC.B.3d).

"Kalau masalahnya berat suka jadi pikiran, paling diem di rumah nggak kemana-mana." (S1.EFC.B.3h).

“...ke anak kadang suka ngemarahin kalau lagi nggak sadar. Padahal anak kan nggak dosa malah jadi pelampiasan. Pernah anak saya sampai nangis kalau saya ada masalah sama suami, anak suka saya cubit sampe nangis kalau saya lagi nggak sadar.” (S1.EFC.B.3f).

Seeking social support. Saat ada masalah, $\mathrm{R}$ mencari dukungan dengan menceritakan masalahnya kepada orang yang dipercaya yaitu teman dekatnya baik bercerita langsung maupun telepon. Selain itu dirinya juga mendapat dukungan emosional dari saudaranya dengan menerima saran dan membantu menyampaikan keinginan pada ibunya.

"Suka main aja ke rumah temen, walaupun udah pindah tetep aja curhat lewat telepon" (S1.EFC.C.2b).

"Saya suka curhat kalau lagi ada masalah, mereka suka ngebantuin. Ya ngasih masukan atau suka bantuin ngomong keinginan saya ke orangtua." (S1.EFC.C.4a).

Accepting responsibility. $\mathrm{R}$ menyadari saat dihadapkan pada masalah bahwa ada sifatnya yang sulit dirubah sejak kecil yang merugikan dirinya yaitu suka mengalah dan memendam rasa kesal karenamerasa segan dan tidak berani untuk mengungkapkan perasan pada siapapun. $R$ menyadari sifatnya harus dirubah agar lebih berani dalam menyampaikan perasaan, jangan mudah berkecil hati, jangan terlalu merasa kasihan pada orang lain dan jangan terlalu mengalah saat ada masalah.

"Segan, nggak berani ngomong. Waktu itu saya pernah diobatin Ustadz, diramal katanya saya punya sifat nggak tegaan." (S1.EFC.D.2a).

"Eu..mungkin saya harus lebih berani, jangan kecil hati, jangan gampang kasian ke orang” (S1.EFC.D.3a).
"Ya paling jangan gampang ngalah, kan sifat saya mengalah ya lebih baik diam kalau ada apa-apa." (S1.EFC.D.3b).

Escape/avoidance. Saat ada masalah, dirinya pernah berpikir untuk melarikan diri dari rumah karena merasa sangat kesal dengan keadaan karena pihak orangtua yang membuat dirinya dan suami hampir bercerai. $\mathrm{R}$ sadar bahwa dengan menghindari masalah tidak aka nada jalan keluar, memendam rasa kesal terlalu lama membuat dirinya terbebani dan akibatnya mempengaruhi kondisi kesehatannya mulai dari kehilangan selera makan hingga berat badan yang menurun.

"Pernah ada pikiran mau kabur, kejadiannya pas udah nikah, baju udah diberesin tapi banyak yang ngehalangin pada cegah saya. ya jadi gitu kalau kesel suka nggak mau ada di rumah." (S1.EFC.E.1a).

"Ya makanya sering jadi beban pikiran" (S1.EFC.E.4a).

Positive reappraisal. R selalu berdo'a kepada Allah meminta agar diberi jalan keluar dari masalahnya. Di balik adanya masalah $\mathrm{R}$ merasa mendapat hikmah dimana dirinya saat ini menjadi lebih dewasa, lebih menyadari peran dalam keluarga, merasa lebih sabar dan memiliki rasa tanggung jawab, dirinya yakin bahwa Allah membantu tiap masalahnya, buktinya orangtuanya menjadi sadar dan bisa menerima kembali keadaan suami R.Selain berdo'a juga membiasakan diri untuk sholat tahajjud dan mengikuti pengajian di madrasah sehingga dirinya merasa tenang dan mendapatkan pencerahan.

"Ya saya berdo'a kepada Allah minta agar dikasih jalan keluar.” (S1.EFC.F.2a).

"Berdo'a, sholat tahajjud kalau bangun itu juga. Saya suka ikut pengajian kalau ada." (S1.EFC.F.4a).

"Hm ada sih. Saya jadi lebih dewasa, terus jadi berpikir kalau adatnya jangan disamain kaya saya waktu kecil apalagi sekarang saya kan udah punya suami dan anak. Dan saya ngerasa lebih sabar, gitu kayanya. Sama ngerasa punya tanggung jawab kalau saya 
sekarang udah berumahtangga."

(S1.EFC.F.1b).

Penyelesaian fokus masalah.

Planful problem soving. Saat ada masalah besar yang menimpanya pada tahun 2012 dirinya tidak diam saja, tetapi berusaha untuk melakukan yang terbaik dalam mempertahankan rumah tangganya dengan membeli handphone baru dan menghubungi suaminya agar kembali ke rumahnya dan tidak bercerai dengannya, dirinya memikirkan upaya yang dilakukan serta dampak yang akan terjadi ke depannya.

"Dulu Hp dan kartu saya diambil orangtua, tapi saya ngusahain beli Hp lagi pake uang tabungan sendiri demi rumah tangga saya jangan sampai bercerai. Saya mikir karena ini masalah bukan datang dari saya jadi saya berusaha buat mempertahankan. Terus saya ngehubungin si Aa lewat facebook supaya bisa tinggal serumah lagi." (S1.PFC.G.2b).

"Ya dipikirin dulu cara nyeleseinnya gimana. Tapi kalau ada masalah, saya nggak pernah minta maaf gimana ya sifatnya saya keras kepala. Terus suka dipikirin juga dampaknya gimana. Kadang kalau ada omongan nggak enak terus saya lawan, saya suka mikir nggak mau berantem percuma masalahnya bakal jadi panjang. Jadi saya lebih baik ngalah. Kalau masalah kecil suka biasa aja didiemin. Kalau masalahnya rumit dan bikin hati saya sakit suka jadi kepikiran.” (S1.PFC.G.3a).

\section{Subyek 2 (S)}

$\mathrm{S}$ adalah seorang perempuan yang saat ini berusia 25 tahun. S dilahirkan di Bandung, 28 Januari 1992. S merupakan anak kedua dari pasangan A dan N. Memiliki satu kakak lakilaki yang kini sudah berumah tangga. S menempuh pendidikan terakhirnya di bangku Sekolah Dasar (SD) pada tahun 2005, tidak melanjutkan sekolahnya ke SMP karena keterbatasan biaya juga lingkungan tempat tinggal $S$, teman-temannya banyak yang tidak bersekolah. Pada akhirnya S memutuskan untuk menikah pada tahun 2007 saat usianya menginjak 15 tahun dengan laki-laki tersebut yang berusia 20 tahun.

Saat menikah $\mathrm{S}$ belum memiliki kartu tanda penduduk (KTP) karena usianya masih dibawah 17 tahun. Di lingkungan tempat tinggal $\mathrm{S}$, peranan adat menikah dini masih berlangsung hingga saat ini. S mengatakan seringkali anak perempuan umur belasan tahun jadi bahan pembicaraan apabila belum menikah. S merasa bahagia karena dapat menikah dengan laki-laki yang dicintai kemudian saat berusia 16 tahun.

$\mathrm{S}$ melahirkan anak pertama berjenis kelamin laki-laki secara normal di rumah oleh bantuan Bidan desa pada tahun 2010. saat ini sudah berusia 7 tahun dan sedang duduk di bangku kelas $2 \mathrm{SD}$. S pun tengah bahagia karena sedang menanti kelahiran anak keduanya yang masih di dalam kandungan berumur 4 bulan. Saat ini usia pernikahan $\mathrm{S}$ sudah menginjak 10 tahun. Berbagai masalah telah dilewati. S menyadari karena menikah saat itu masih 15 tahun jadi seringkali terjadi kesalahpahaman.

Menurut S, faktor pendukung terjadinya pernikahan dini karena seringnya anak perempuan jadi bahan pembicaran dan adanya istilah "dareet jodo." Istilah tersebut menggambarkan adanya rasa takut dan kekhawatiran orangtua pada anaknya yang tak kunjung menikah. Maka dari itu, jika sudah ada jodohnya sekalipun sedang duduk di bangku sekolah orangtuanya akan segera menikahkan dan memilih untuk mengeluarkan anaknya dari sekolah. Setelah menikah, S dihadapkan pada berbagai masalah meliputi salah paham diantara dirinya dengan suami, merasa kesal saat harus melakukan tugas rumah tangga, masalah dari anak, dan kebutuhan ekonomi.

\section{Penyelesaian fokus emosi.}

Distancing. Saat ada masalah, S memilih mengalah menghindari pertengkaran, atau menghindar dengan mengunjungi tetangganya. Walaupun menghindar, $\mathrm{S}$ yakin keadaannya nanti akan kembali seperti semula.

"Paling teteh suka ngalah aja pikirnya nanti juga suka cair lagi. Jadi nggak akan memperpanjang masalah.” (S2.EFC.A.2a).

"Kadang kalau lagi berantem suka salah satunya pergi aja kemana gitu lagian kalau marah nggak lama, nanti juga akur lagi." (S2.EFC.A.2c).

"Apa ya paling teteh suka keluar rumah aja ke tetangga nggak ngeliatin lagi punya masalah. Lagian kalo teteh punya masalah suka 
sebentar, nggak enak kalau berantem kan rumahnya kecil jadi ketemu terus nanti juga akur lagi." (S2.EFC.A.4a).

"Ah teteh sih bebas aja nggak dipikirin terusterusan yang penting nanti masalahnya beres aja gitu." (S2.EFC.A.4b).

Self control. Saat ada masalah, S merasa kesal namun saat kesalnya melampui kesabaran, sesekali $\mathrm{S}$ melampiaskan pada anaknya.

"Sesekali suka kesel ke si Aa tapi jadinya ke anak sendiri marahnya, seenggaknya agak lega udah ngelampiasin walaupun itu teh anak sendiri..” (S2.EFC.B.3b).

Seeking social support. Saat ada masalah, $\mathrm{S}$ biasanya menyempatkan untuk berkumpul dengan saudaranya tanpa memperlihatkan sedang ada masalah. Bagi $\mathrm{S}$, yang selalu berperan dalam membantu menyelesaikan masalah adalah ibu dan saudaranya, keduanya sering memberikan saran berdasarkan pengalaman.

"Ngumpul sama saudara tapi ya jangan ngeliatin lagi ada masalah jadi kan nggak begitu inget sama masalahnya." (S2.EFC.C.1a).

"Paling saudara sama si Mama."
(S2.EFC.C.3a).

"Ya ngasih saran gitu kalau selama rumah tangga suka ada masalah yang nggak bisa dihindari. Paling ngasih tau ke saya kalau saya harus gini harus gitu, ya mungkin menurut pengalaman mereka juga." (S2.EFC.C.4a).

Accepting responsibility. $\mathrm{S}$ memiliki kesulitan saat menghadapi masalah, sifatnya takut dan mudah berkecil hati membuat pesimis. Namun S menempatkan segala sesuatu dengan sebagaimana mestinya. S menyadari peran yang seharusnya dilakukan berusaha untuk menyadari kesalahan dan saling meminta maaf hingga saat ini $\mathrm{S}$ bersyukur karena tidak ada masalah yang merepotkan kedua orangtuanya.

"Kesulitannya paling suka berkecil hati, suka ada perasaan takut nggak selesai masalahnya." (S2.EFC.D.1a).
"Sadar diri aja kerasa sama teteh. Kan teteh udah 10 taun nikah. Alhamdulillah nggak pernah ada masalah besar sampai orangtua tau gitu. paling kita sendirinya harus sadar aja harus ngelakuin apa." (S2.EFC.D.3b).

"Kalau kesalahan ada di diri si Aa ya berarti Aa yang minta maaf. Tapi kalau kesalahan ada di diri teteh ya teteh yang minta maaf..paling gitu.." (S2.EFC.D.3c).

Escape/avoidance. Saat-saat tertentu, S menghindari masalah dengan pergi mengunjungi saudara atau tetangganya. Walaupun tertawa lepas saat berkumpul tetapi S merasa cemas dan selalu terbayang akan masalah.

"Kalau teteh sih paling ngumpul walaupun lagi ngobrol gitu ketawa lepas tapi kadang suka inget sama masalah ini sama masalah itu” (S2.EFC.E.1a).

"Perasaannya cemas gitu, takut si Aa nggak terima” (S2.EFC.E.2a).

"Suka ngebayangin aja gitu takut masalahnya nggak selesai.” (S2.EFC.E.3a).

Positive reappraisal. Saat ada masalah S seringkali mengendalikan emosi dengan berIstighfar. $S$ yakin Allah menolong tiap masalahnya dengan sholat dan berdo'a khusyu. $S$ merasa mendapat hikmah di balik masalahnya, jadi lebih bisa membenahi diri dan dewasa.

"Teteh sih biasanya istighfar." (S2.EFC.F.1a).

"Ya percaya. Kerasa sama teteh kalau lagi ada masalah selalu ada jalan keluarnya." (S2.EFC.F.3a).

"Sholat da udah pasti kan kewajiban. Ibaratnya gitu kalau lagi ada masalah, jadi makin khusyu sholatnya, Cuma bedanya kalau lagi sholat suka lama gitu ngedo'anya." (S2.EFC.F.4a).

"Ya mungkin karena ada masalah, hikmahnya teteh harus lebih bisa membenahi diri sendiri, jadi ngelatih diri harus lebih dewasa gitu.." (S2.EFC.F.2a). 
Penyelesaian fokus masalah.

Planful problem solving. Sebelum melakukan sesuatu, $\mathrm{S}$ memikirkan upaya yang dilakukan selama masih bisa diselesaikan berdua tidak pernah meminta bantuan pada orang tua. S selalu menghadapi masalahnya, biasanya langsung mengutarakan pada suami dan mendiskusikan masalahnya agar cepat selesai. Ini adalah cara penyelesaian masalah yang selama ini dilakukan agar mencegah perdebatan antara $\mathrm{S}$ dan suaminya.

"Ngomong langsung aja ke si Aa biar lega perasaannya nggak ada beban apa-apa jadi nggak terlalu kesel.." (S2.PFC.G.2a).

"Ya kalau teteh sih suka dipikir dulu masalahnya apa..siapa yang salah..siapa yang minta maaf.. kalau kesalahan ada di si Aa teteh yang minta maaf kadang-kadang karena nggak mau masalahnya jadi besar ya amit-amit gitu ya kalau nggak dipikir dulu suka jadi berantem lama.."( S2.PFC.G.3a).

\section{Subyek 3 (C)}

$\mathrm{C}$ adalah seorang remaja perempuan yang saat ini berusia 17 tahun, dilahirkan di Bandung pada tanggal 28 Agustus 2000. C merupakan anak pertama dari tiga bersaudara dari pasangan $\mathrm{E}$ dan $\mathrm{Y}$. Kedua orangtuanya bercerai 4 tahun yang lalu, saat ini $\mathrm{C}$ tinggal bersama ibu kandung, adik dan ayah tirinya.C menempuh pendidikan terakhir di bangku SMP Negeri pada tahun 2014, tidak melanjutkan ke SMA karena keterbatasan biaya.C dikenalkan ayah tirinya dengan Laki-laki tersebut bernama A berusia 26 tahun. $\mathrm{C}$ mengenal A selama 2 tahun berawal dari tahun 2013, tidak lama kemudian ayah tirinya meminta agar menikah dengan A. Di lingkungan tempat tinggalnya, pernikahan anak di bawah 17 tahun seringkali dilakukan karena adanya peranan adat yang kuat.. Saat itu C merasa bingung karena di satu sisi, tidak menyukai A dan sisi lain tidak dapat menolak permintaan ayah tirinya.

Pada akhirnya $\mathrm{C}$ memutuskan untuk menikah dengan A pada tahun 2015 di usianya yang menginjak 15 tahun. Setelah menikah, C dan A tinggal bersama di tempat tinggal orangtua $\mathrm{C}$ dan sesekali menginap di rumah mertuanya. $\mathrm{C}$ telah menjalani pernikahan kurang lebih selama satu setengah tahun dengan A.
Banyak masalah yang dihadapinya, saat itu C bekerja sebagai ibu rumah tangga sedangkan A bekerja sebagai buruh ternak ayam. C merasa suaminya tidak bertanggung jawab karena segala kebutuhan rumah tangga ditanggung oleh ibunya bahkan dirinya tidak diberi nafkah oleh suaminya. Dirinya merasa kesal biasanya $\mathrm{C}$ memilih untuk lebih mengalah demi menghindari pertengkaran. Seringkali salah paham diantara keduanya karena masalah handphone dan facebook. C mengatakan bahwa dirinya sama sekali tidak bahagia dan merasa tertekan menjalani hari-hari sebagai istri A.

Namun $\mathrm{C}$ tidak berani mengungkapkan perasannya pada ayah tirinya karena takut menyakiti hati. $\mathrm{C}$ juga lebih memilih untuk diam dan memendam semuanya karena $\mathrm{C}$ merasa segan dan takut pada A yang usianya lebih tua darinya. kemudian $\mathrm{C}$ memberanikan diri untuk berbicara kepada ayah tirinya bahwa dirinya sudah tidak tahan dengan keadaan rumah tangganya, orangtua nya pun merasa kasihan kepada anaknya dan pada akhirnya $\mathrm{C}$ memutuskan untuk memilih bercerai dengan A. Kini status $\mathrm{C}$ sudah menjadi janda di usianya yang baru menginjak 17 tahun.

\section{Penyelesaian fokus emosi.}

\section{Self control.}

C merasa sedih, menyesal dan marah saat menyadari banyak masalah yang dialami namun selalu dipendam sendiri.

"Ya sedih gitu, nyesel, marah tapi ah dipendem aja." (S3.EFC.B.1b).

"Gimana ya paling dipendem nggak pernah ngomong saya mah.” (S3.EFC.B.3b).

"Ya kalau punya masalah dipendem aja sendiri." (S3.EFC.B.3c).

"Apa ya, diem aja nggak pernah ngomomg. Kalau ngomomg malah saya yang dimarahin." (S3.EFC.B.3d).

"Apa ya saya sih dipendem aja." (S3.EFC.B.3e).

\section{Seeking social support.}

Saat ada masalah biasanya $\mathrm{C}$ menceritakan kepada ibunya dan mendapat saran juga motivasi bagi dirinya. 
"Ya paling curhat ke mama gitu minta saran." (S3.EFC.C.3b).

"Ya suka ngasih saran gitu katanya biarin aja nanti juga sadar sendiri.” (S3.EFC.C.4a).

\section{Accepting responsibility.}

C sadar pikirannya belum dewasa dan selalu memendam perasaan membuat dirinya kesulitan saat menghadapi masalah.

"Ya mungkin saya belum ngerasa berumah tangga, pikirannya masih anak kecil." (S3.EFC.D.3a).

"Ya kalau punya masalah suka dipendem nggak diungkapin." (S3.EFC.D.1a).

"Ya saya nggak berani kalau ngomong langsung, umurnya kan jauh jadi segan terus nggak cinta jadi canggung." ( S3.EFC.D.2a).

"Ya harus lebih berani. Mungkin ini udah takdir saya harus gini jalannya. (S3.EFC.D.2a).

\section{Escape/ avoidance.}

$\mathrm{C}$ menghindari masalah dengan melarikan diri saat tinggal di rumah mertuanya. Selain itu biasanya $\mathrm{C}$ mengunci diri di rumah dan melamun membayangkan masalahnya, karena banyak pikiran $\mathrm{C}$ sempat sakit dan dirawat di rumah sakit.

"Saya juga sadar dengan cara kabur nggak akan selesai tapi saya males jadi masalah" (S3.EFC.E.3c).

"Paling kabur ke rumah mama."
(S3.EFC.E.3f).

"Suka kadang ngehindar lebih milih kabur ke rumah mamah.” (S3.EFC.E.3g).

"Saya sih sering kepikiran gitu terus-terusan sebelum masalahnya selesai.” (S3.EFC.E.3c).

"Ngelamun aja, kalau lagi di rumah paling ngunci diri sendiri nggak pergi gitu." (S3.EFC.E.3e).
"Ya jadi suka terus kepikiran tiap hari sepanjang masalahnya belum selesai, makanya jadi beban pikiran buat saya." (S3.EFC.E.4a).

\section{Positive reappraisal.}

C mendekatkan diri pada Allah dengan sholat dan mengikuti pengajian. $\mathrm{C}$ percaya bahwa Allah akan memberinya jalan keluar dari masalahnya, C merasa mendapat hikmah dirinya menjadi lebih sabar, pemaaf dan lebih dewasa. Saat ini C menerima keadaan dan menjadikan kejadian tersebut pelajaran untuk ke depannya agar bisa memilih pasangan sesuai keinginan sehingga hidupnya menjadi lebih baik.

"Saya suka sholat sama ikut ke pengajian mama." (S3.EFC.F.4a).

"Jadi makin tabah, sabar, lebih pemaaf dan lebih dewasa." (S3.EFC.F.1a).

"Apa ya lebih nerima keadaan aja biar jadi pelajaran ke depannya buat saya. Sekarang saya masih kecil umur juga belum dewasa tapi istilahnya udah nggak punya suami ya nerima aja mungkin waktu itu pernah ngelakuin kesalahan walaupun kesalahannya bukan ada di saya." (S3.EFC.F.1b).

\section{Penyelesaian fokus masalah.}

\section{Confrontative coping.}

C merasa kesal dan seringkali mencoba menghindari masalah, yang ada di benaknya saat itu hanyalah ingin berpisah. $\mathrm{C}$ sudah menerima keadaan dan berani mengambil resiko yang terjadi pada dirinya dan berharap berpisah akan membuat keadaannya lebih baik.

"Kadang suka ngehindar lebih milih kabur ke rumah mama, nggak mau pulang lagi kesana. Yang ada di pikiran Cuma satu pengen udahan gamau kesana lagi.” (S3.PFC.H.1b).

"Ya gitu ngomong ke mama saya pengen udahan, saya lebih milih dibilang janda sama tiap orang daripada dipaksain terus saya nggak betah nggak cinta. Mudah-mudahan ke depannya saya bisa lebih baik dari ini." (S3.PFC.H.2a).

Berdasarkan hasil wawancara, penggunaan kedua koping yang dilakukan oleh ketiga subyek sesuai dengan teori Lazarus \& Folkman (1984) bahwa untuk mencapai koping 
yang efektif diperlukan penggunaan dari keduanya. Terdapat persamaan penggunaan bentuk koping yang dilakukan oleh ketiga subyek saat menghadapi masalah yaitu bentuk koping penyelesaian emosi atau emotionfocused coping $(E F C)$ dan koping penyelesaian masalah atau problem-focused coping (PFC).

Bentuk koping penyelesaian emosi digunakan subyek untuk menyesuaikan diri dalam mengatasi tekanan dengan cara mengatur respon emosional dan bentuk koping penyelesaian masalah digunakan subyek untuk mengubah masalah yang dihadapi dari lingkungan yang menyebabkan tekanan. Dalam teori Lazarus (1984) terdapat aspek positive reappraisal pada bentuk koping penyelesaian emosi atau emotion-focused coping (EFC), bentuk koping ini dilakukan dengan cara menciptakan pandangan positif dan memusatkan pada pengembangan personal. Positive reappraisal berpengaruh pada tingkat stress yang rendah dan kualitas hidup yang lebih baik.

Islam secara umum memerintahkan umatnya untuk selalu mendekatkan diri kepada Allah. Berpasrah diri kepada Allah akan membantu umatnya dengan cara yang tidak disangka-sangka. Dalam kandungan ayat AlAhzab ayat 38 disebutkan bahwa ketetapan Allah itu suatu ketetapan yang pasti berlaku, hal ini bermaksud bahwa dalam Islam kehidupan manusia itu telah ditentukan ketetapannya yakni qada' dan qadar-Nya. Maka dari itu selain berusaha, manusia harus ikhlas menerima kenyataan dan berpasrah diri pada Allah sehingga stressor bisa dihadapi dengan baik.

Pembahasan berikutnya perbandingan positive reappraisal yang digunakan ketiga subyek dalam menghadapi masalahnya. Pada subyek kesatu, upaya penyelesaian masalah dilakukan dengan mendekatkan diri kepada Allah dengan melakukan sholat tahajjud dan mengikuti pengajian. Mengikuti pengajian atau ceramah dapat meningkatkan iman dan takwa seseorang. Dalam kandungan surat Al Baqarah ayat 155 disebutkan bahwa Allah memberi cobaan dengan ketakutan, kelaparan, kekurangan harta, jiwa dan buah-buahan. Isi ayat tersebut menegaskan bahwa Allah senantiasa akan menguji hambaNya dengan banyak cobaan untuk melihat seberapa kuat iman hambaNya. Ujian akan menimbulkan banyak tekanan dalam jiwa manusia, dalam menghadapinya manusia tidak hanya dituntut untuk melakukan penyesuaian secara fisik, psikis dan sosial tetapi dituntut untuk mampu mempertahankan penyesuaian spiritual dengan mempertahankan keimanannya kepada Allah.

Pada subyek kedua, dirinya selalu berusaha untuk segera menyelesaikan dan meminta pertolongan pada Allah. Hal ini sesuai dengan kandungan dari surat Ar-Rad ayat 11 bahwa Allah tidak akan mengubah keadaan suatu kaum sehingga mereka mengubah keadaan dirinya sendiri. Menurut As Samarqandhi tafsir dari ayat tersebut terdapat peringatan kepada manusia agar mengenali nikmat Allah dan mensyukurinya kemudian Allah menegaskan saat ada masalah, manusia tidak diperkenankan berpasrah diri dan berpangku tangan menyerahkan semua urusan kepada Allah tetapi harus melakukan usaha dalam menghadapi segala ujian sehingga manusia diwajibkan untuk melakukan usaha yang disebut ikhtiar. Ikhtiar berarti fokus pada masalah dimana individu mencoba menghilangkan tekanan yang dialami dengan berusaha mengubah perilaku aktif yang bertujuan untuk memecahkan masalah yang dihadapi.

Pada subyek ketiga dalam penyelesaian masalah dirinya cenderung menghindari masalah dengan melamun dan menangis. Walaupun begitu dirinya tetap meminta pertolongan kepada Allah dengan berdo'a dan sholat. Rasa sedih ini merupakan reaksi emosi akibat dari tekanan yang dapat berbentuk perilaku murung, diam, pesimis, tertekan dan sering diekspresikan dengan menangis. Ketidak berdayaan tersebut sebetulnya dapat diatasi dengan keyakinan kuat bahwa tiap manusia memiliki kekuatan untuk menghadapinya karena Allah tidak akan memberi kesulitan di luar kemampuan manusia. Dalam surat AlBaqarah ayat 286 disebutkan bahwa Allah tidak akan membebani seseorang melainkan sesuai dengan kemampuannya, hal ini mengandung makna bahwa sebetulnya Islam memberikan dukungan secara emosional dan perlindungan kepada manusia saat mengalami tekanan yakni dengan mendekatkan diri kepada Allah SWT.

\section{Perbandingan Gambaran Penyelesaian Koping Emosi}

Dalam penggunaan aspek distancing hanya dilakukan oleh subyek kedua dimana dirinya menghindari masalah namun tetap menciptakan pandangan positif. $\mathrm{S}$ menghindari masalah 
dengan pergi berkumpul ke rumah tetangga tetapi tidak memperlihatkan sedang ada masalah dan yakin bahwa keadaannya akan kembali seperti semula. Sedangkan penjelasan pada subyek kedua dan subyek ketiga tidak menunjukkan adanya upaya distancing.

Dalam penggunaan aspek self control terdapat persamaan dari ketiga subyek, emosi yang muncul saat menghadapi masalah yaitu sedih, kesal dan marah. Persamaan lain terjadi pada subyek kesatu dan kedua di saat tertentu melampiaskan pada anak saat emosinya melampaui batas kesabaran. Perbedaan dari ketiga subyek terlihat dari cara mengendalikan diri saat menghadapi masalah. Subyek kesatu mengendalikan diri dengan menangis dan bercerita kepada temannya. Subyek kedua selalu berbicara mengutarakan langsung pada suami dan subyek ketiga memilih diam memendam perasaan dan tidak bercerita pada siapapun.

Dalam penggunaan aspek seeking social support terdapat persamaan dari ketiga subyek yaitu mendapat dukungan dari orang terdekat berupa saran dan motivasi dalam menyelesaikan masalah. Ketiga subyek selalu bercerita langsung terhadap orang terdekatnya. Perbedaannya terletak pada orang yang berperan dalam memberikan dukungan emosional. Subyek kesatu mendapat dukungan dari teman dan saudaranya. Subyek kedua dari ibu dan saudaranya dan subyek ketiga dari ibunya.

Dalam penggunaan aspek accepting responsibility, terdapat persamaan pada ketiga subyek yang merasa takut menyampaikan perasaan kepada suami. Mereka menyadari kesulitan yang ada dalam dirinya saat menghadapi masalah, dalam hal ini terdapat persamaan antara subyek kesatu dan ketiga yaitu sifatnya suka mengalah, memendam perasaan dan membebani pikirannya sendiri namun mereka menyadari peran yang harus dilakukan yaitu lebih berani dalam mengungkapkan perasaan. Beda halnya dengan subyek kedua yang menyadari sifatnya pesimis dan mudah berkecil hati membuatnya sulit saat menghadapi masalah, dirinya mencoba menempatkan sebagaimana mestinya dengan selalu optimis dan meminta maaf apabila melakukan kesalahan.

Dalam penggunaan aspek escapel avoidance ketiga subyek sama-sama menghindar saat ada masalah. Perbedaannya terletak pada cara yang dilakukan. Subyek kesatu pernah mencoba melarikan diri dari rumah. Subyek kedua menghindar dengan pergi ke rumah tetangganya walaupun hatinya cemas memikirkan masalahnya. Subyek ketiga menghindar dengan menyendiri memikirkan masalah dan melarikan diri dari rumah mertuanya.

Dalam penggunaan aspek positive reappraisal, terdapat persamaan dari ketiga subyek yang meyakini dengan berdo'a Allah akan memberikan pertolongan. Selain itu mereka mendekatkan diri pada Allah dengan sholat dan mendengarkan ceramah di pengajian. Perbedaannya terlihat pada subyek kesatu yang selalu bersikap pasrah dan subyek kedua selalu mengucapkan kalimat istighfar untuk mendapat ketenangan hatinya.

\section{Perbandingan Gambaran Penyelesaian Koping Masalah}

Pada penggunaan aspek planful problem solving terdapat persamaan antara subyek kesatu dan kedua yang selalu memikirkan upaya yang dilakukan dalam menyelesaikan masalah dan selalu mempertimbangkan dampak yang terjadi. Perbedaannya, pada subyek kesatu karena merasa segan jadi sesekali mencoba memberanikan diri berbicara pada suaminya sedangkan pada subyek kedua dirinya tidak suka memendam masalah terlalu lama jadi selalu mengutarakan langsung pada suami dan mengevaluasi penyebab timbulnya masalah. Sedangkan pada subyek ketiga tidak menunjukkan adanya upaya penyelesaian planful problem solving sebab dirinya selalu menghindari masalah tanpa ada keinginan untuk memperbaiki masalah dengan suaminya.

Pada penggunaan aspek confrontative coping, hanya dilakukan oleh subyek ketiga. Seringkali menghindari masalah dengan kabur dari rumah mertuanya ke rumah ibu nya. Selain itu dirinya berani mengambil resiko dengan memilih untuk bercerai dengan suami karena merasa tertekan selama menjalani pernikahan. Sedangkan pada subyek kesatu dan kedua dalam penyelesaian masalah tidak menunjukkan adanya upaya pengambilan resiko karena keduanya selalu berupaya untuk segera memperbaiki masalah dengan cara yang analitis, bertahap, dan hati-hati.

\section{Perbandingan Penggunaan Koping}

Secara umum subyek kesatu menggunakan 1 aspek penyelesaian fokus 
masalah yaitu planful problem solving dan menggunakan 5 aspek penyelesaian fokus emosi yaitu self control, seeking social support, accepting responsibility, escapelavoidance dan positive reappraisal.

Subyek kedua menggunakan 1 aspek penyelesaian fokus masalah yaitu planful problem solving dan menggunakan 6 aspek penyelesaian fokus emosi yaitu distancing,self control, seeking social support, accepting responsibility, escapel avoidance dan positive reappraisal.

Subyek ketiga menggunakan 1 aspek penyelesaian fokus masalah yaitu confrontative solving dan menggunakan 5 aspek penyelesaian fokus emosi yaitu self control, seeking social support, accepting responsibility, escapel avoidance dan positive reappraisal.

\section{Perbandingan Dampak Penggunaan Koping}

Dampaknya menunjukkan bahwa ketiga subyek cenderung menggunakan penyelesaian fokus emosi, kemudian peneliti mengkategorikan dampak tersebut menjadi dua kategori yaitu emosi positif dan dukungan sosial.

Kategori pertama, emosi positif yakni perasaan atau emosi yang menunjukkan keadaan dirinya lebih baik dari sebelumnya yang dirasakan oleh ketiga subyek saat menggunakan bentuk koping aspek accepting responsibility.

Pada subyek kesatu dampak yang dirasakan yakni dirinya dapat lebih mengendalikan diri, menjadi lebih sabar dan optimis dalam menghadapi tiap masalah. Pada subyek kedua, dirinya dapat lebih mengendalikan perasaannya, lebih mandiri dan hatinya merasa tenang karena masalahnya dapat segera terselesaikan. Dan pada subyek ketiga, dirinya menjadi lebih hati-hati dalam mengambil keputusan, lebih sabar, pemaaf, dan berpikir jauh ke depan sebelum melakukan sesuatu.

Kategori kedua, dukungan emosional yakni bantuan secara langsung atau tidak langsung baik diperoleh dari orang terdekat, lingkungan maupun berupa informasi yang dapat memberikan dukungan emosional secara positif bagi diri subyek.

Pada subyek kesatu, dirinya mendapat bantuan dari teman dekat dan saudara yang membantu menyelesaikan masalah sehingga perasaannya menjadi lega. Pada subyek kedua, dirinya mendapat bantuan dari ibu dan saudara berupa saran dan pengalaman yang membantu meringankan beban pikiran sehingga perasaannya menjadi tenang. Dan pada subyek ketiga dirinya mendapat bantuan dari ibunya dalam bentuk saran sehingga perasaannya menjadi lega dan termotivasi.

\section{Perbandingan Penggunaan Koping Dominan dan Tidak Dominan}

Ketiga subyek cenderung menggunakan dimensi penyelesaian fokus pada emosi dalam upaya penyelesaian masalahnya. Hal ini terlihat dari aspek dominan yang digunakan merupakan bagian dari penyelesaian fokus emosi atau emotion-focused of coping.

Aspek dominan menunjukkan penggunaan koping paling menonjol yang digunakan oleh ketiga subyek, sedangkan aspek tidak dominan menunjukkan penggunaan koping paling tidak menonjol dalam upaya penyelesaian masalah yang digunakan oleh ketiga subyek. Apabila dilihat dari keseluruhan, maka aspek dominan yang digunakan oleh subyek kesatu dalam penyelesaian masalah yaitu self control dan aspek yang tidak dominan yaitu distancing dan confrontative coping. Aspek self control menjadi paling dominan karena apabila melihat posisi dalam keluarga kini dirinya merupakan anak yatim piatu dan anak tunggal sehingga dirinya menyesuaikan diri dengan kondisi lingkungan yang secara tidak langsung menuntut dirinya agar dapat bersikap lebih dewasa dalam menyikapi masalah. Selanjutnya aspek yang tidak dominan adalah distancing dan confrontative coping hal ini berkaitan dengan alasan menikah yakni kemauan sendiri, dirinya menikah karena didasari perasaan saling suka dan sayang satu sama lain dengan suami sehingga saat ada masalah dirinya selalu berupaya untuk mempertahankan keadaan rumah tangganya dengan cara melakukan upaya terbaiknya agar dapat tetap tinggal bersama dengan suami.

Pada subyek kedua, aspek paling dominan digunakan dalam penyelesaian masalah yaitu planful problem solving dan yang tidak dominan yaitu confrontative coping. Aspekplanful problem solving menjadi paling dominan karena apabila melihat riwayat hidupnya, dirinya tinggal di lingkungan dimana dirinya mendapatkan kasih sayang dan perhatian utuh dari orangtua kemudian dirinya melihat figur kedua orangtua yang terlihat harmonis dan segera mendiskusikan apabila ada masalah maka dari itu dirinya melakukan 
upaya yang sama saat menyelesaikan masalah sehingga dirinya dapat lebih mengontrol dirinya baik perasaan maupun tindakan. Selanjutnya aspek yang tidak dominan adalah distancing dan confrontative coping apabila melihat riwayat hidup, dirinya menikah dengan seorang lelaki yang usianya lebih tua lima tahun sehingga dirinya merasa terbawa menjadi lebih dewasa dalam menyikapi hal apapun. Dirinya menikah karena keinginan sendiri yang didasari rasa saling suka dan saling sayang sehingga dalam upaya penyelesaian masalah dirinya tidak mencoba untuk menghindari dan mengambil tindakan yang beresiko tetapi dirinya selalu memikirkan upaya terbaik dan segera mengajak diskusi suami agar masalahnya dapat segera terselesaikan

Pada subyek ketiga, aspek paling dominan digunakan dalam penyelesaian masalah yaitu escape/avoidance dan yang tidak dominan yaitu distancing dan planful problem solving. Aspek escapelavoidance ini paling dominan sebab apabila menggali riwayat hidupnya terlihat bahwa relasi dirinya dengan suami tidak berjalan dengan baik, pernikahan karena paksaan dan desakan dari orangtua membuat dirinya tertekan dan menganggapnya suatu beban dalam menjalani pernikahan, dirinya tidak memiliki perasaan suka ataupun sayang terhadap suami dan merasa belum siap untuk menjadi seorang isteri dalam usianya yang masih belia maka dari itu cara penyelesaian masalah yang paling sering dilakukan adalah dengan cara menghindari masalah, menjauhi suami, memilih untuk lari dari rumah mertua dan memendam segala perasaannya.

Sedangkan aspek yang tidak dominan adalah distancing dan planful problem solving, hal ini terjadi karena adanya paksaan dan desakan dalam menikah sehingga saat ada masalah dirinya tidak ada keinginan untuk memperbaiki hubungannya dengan suami tetapi yang dilakukan adalah upaya untuk mengakhiri segala hubungannya dengan suami maka dari itu dirinya memilih untuk mengambil resiko dengan memutuskan untuk bercerai di usianya yang masih tujuh belas tahun.

Dalam temuan hasil penelitian ini menunjukkan bahwa dalam upaya penyelesaian masalahnya ketiga subyek remaja yang telah menikah menggunakan tiga bentuk penyelesaian koping. Penyelesaian koping tersebut diantaranya terdiri dari dua koping yang sesuai dalam teori dari Lazarus \& Folkman (1984) yaitu penyelesaian fokus pada emosi (emotionfocused of coping) dan penyelesaian fokus pada masalah (problem-focused of coping) dan satu koping temuan baru yakni koping religius dimana ketiga subyek menyelesaikan masalah dengan cara mendekatkan diri kepada Allah. Adapun dampak yang dirasakan ketiga subyek yaitu adanya perasaan atau emosi positif yang menunjukkan keadaan dirinya lebih baik dari sebelumnya. Selain itu ketiga subyek mendapat dukungan sosial secara langsung dan dukungan emosional dari orang-orang terdekat sehingga ketiga subyek dapat optimis dalam menjalankan perannya sebagai isteri dan ibu di usia muda.

Sedangkan pada hasil penelitian sebelumnya, diantaranya hasil penelitian dari Nurdjanah dan Asyanti (2015) hasilnya menunjukkan bahwa penyelesaian koping pada subyeknya sesuai dengan teori Lazarus dan Folkman (1984) yakni lebih cenderung menggunakan penyelesaian pada fokus emosi dan dampak dari penyelesaian fokus emosi adalah subyek merasa lega setelah mendapat dukungan emosional walaupun masalahnya belum terselesaikan sepenuhnya.

Selain itu hasil penelitian dari Khairunnisa dan Setiali (2016) menunjukkan bahwa penyelesaian koping pada subyeknya sesuai dengan teori Lazarus dan Folkman (1984) yakni lebih cenderung menggunakan penyelesaian fokus pada emosi dan dampak dari adanya dukungan sosial dari lingkungan sekitarnya

\section{Simpulan dan Saran}

Berdasarkan pemaparan sebelumnya dapat diambil simpulan penelitian bahwa dalam upaya penyelesaian masalah, ketiga subyek menggunakan tiga bentuk koping. Kedua koping sesuai dengan teori Lazarus dan Folkman (1984) yaitu penyelesaian fokus pada emosi (emotion-focused of coping) dan penyelesaian fokus pada masalah (problem-focused of coping) dan satu koping temuan baru yakni koping religius dimana ketiga subyek menyelesaikan masalah dengan cara mendekatkan diri kepada Allah.

Dari ketiga bentuk koping tersebut, ketiga subyek cenderung menggunakan penyelesaian fokus pada emosi. Adapun gambaran coping strategy yang digunakan ketika subyek 
diantaranya, subyek kesatu (R) menggunakan 1 aspek penyelesaian fokus masalah yaitu planful problem solving dan menggunakan 5 aspek penyelesaian fokus emosi yaitu self control, seeking social support, accepting responsibility, escapelavoidance dan positive reappraisal. Aspek dominan yang digunakan adalah self control.

Subyek kedua (S) menggunakan 1 aspek penyelesaian fokus masalah yaitu planful problem solving dan menggunakan 6 aspek penyelesaian fokus emosi yaitu distancing, self control, seeking social support, accepting responsibility, escapel avoidance dan positive reappraisal. Aspek dominan yang digunakan adalah planful problem solving.

Dan subyek ketiga (C) menggunakan 1 aspek penyelesaian fokus masalah yaitu confrontative solving dan menggunakan 5 aspek penyelesaian fokus emosi yaitu self control, seeking social support, accepting responsibility, escapelavoidance dan positive reappraisal. Aspek dominan yang digunakan adalah escape/avoidance.

Selain itu dalam riset penelitian ini dilakukan perbandingan penyelesaian koping yang dilakukan dan hasilnya menunjukkan terdapat keunikan dari tiap subyek.

Pada subyek kesatu, cenderung menggunakan penyelesaian fokus emosi pada saat menyelesaikan masalahnya. Aspek self control menjadi paling dominan karena apabila melihat posisi dalam keluarga kini dirinya merupakan anak yatim piatu dan anak tunggal sehingga dirinya menyesuaikan diri dengan kondisi lingkungan yang secara tidak langsung menuntut dirinya agar dapat bersikap lebih dewasa dalam menyikapi masalah.

Sedangkan aspek yang tidak dominan adalah distancing dan confrontative coping hal ini berkaitan dengan alasan menikah yakni kemauan sendiri, dirinya menikah karena didasari perasaan saling suka dan sayang satu sama lain dengan suami sehingga saat ada masalah dirinya selalu berupaya untuk mempertahankan keadaan rumah tangganya dengan cara melakukan upaya terbaiknya agar dapat tetap tinggal bersama dengan suami.

Pada subyek kedua, cenderung menggunakan penyelesaian fokus masalah.
Aspek planful problem solving menjadi paling dominan karena apabila melihat riwayat hidupnya, dirinya tinggal di lingkungan dimana dirinya mendapatkan kasih sayang dan perhatian utuh dari orang tua kemudian dirinya melihat figur kedua orangtua yang terlihat harmonis dan segera mendiskusikan apabila ada masalah maka dari itu dirinya melakukan upaya yang sama saat menyelesaikan masalah sehingga dirinya dapat lebih mengontrol dirinya baik perasaan maupun tindakan.

Sedangkan aspek paling tidak dominan adalah distancing dan confrontative coping apabila melihat riwayat hidup, dirinya menikah dengan seorang lelaki yang usianya lebih tua lima tahun sehingga dirinya merasa terbawa menjadi lebih dewasa dalam menyikapi hal apapun. Dirinya menikah karena keinginan sendiri yang didasari rasa saling suka dan saling sayang sehingga dalam upaya penyelesaian masalah dirinya tidak mencoba untuk menghindari dan mengambil tindakan yang beresiko tetapi dirinya selalu memikirkan upaya terbaik dan segera mengajak diskusi suami agar masalahnya dapat segera terselesaikan.

Pada subyek ketiga, cenderung menggunakan penyelesaian fokus masalah. Aspek escape/avoidance paling dominan digunakan sebab apabila menggali riwayat hidupnya terlihat bahwa relasi dirinya dengan suami tidak berjalan dengan baik, pernikahan karena paksaan dan desakan dari orang tua membuat dirinya tertekan dan menganggapnya suatu beban dalam menjalani pernikahan, dirinya tidak memiliki perasaan suka ataupun sayang terhadap suami dan merasa belum siap untuk menjadi seorang isteri dalam usianya yang masih belia maka dari itu cara penyelesaian masalah yang paling sering dilakukan adalah dengan cara menghindari masalah, menjauhi suami, memilih untuk lari dari rumah mertua dan memendam segala perasaannya.

Sedangkan aspek yang tidak dominan adalah distancing dan planful problem solving, hal ini terjadi karena adanya paksaan dan desakan dalam menikah sehingga saat ada masalah dirinya tidak ada keinginan untuk memperbaiki hubungannya dengan 
suami tetapi yang dilakukan adalah upaya untuk mengakhiri segala hubungannya dengan suami maka dari itu dirinya memilih untuk mengambil resiko dengan memutuskan untuk bercerai di usianya yang masih tujuh belas tahun.

Adapun saran dari hasil penelitian tersebut sebaiknya tidak mengambil keputusan secara cepat untuk menikah dini, karena usia yang belum cukup serta tugas perkembangan yang belum terpenuhi akan berdampak pada sisi psikologis dimana akan rentan terjadi pertengkaran bahkan perceraian. Kemudian dalam penelitian selanjutnya diharapkan menggunakan referensi lain yang lebih mudah dipahami dan mencoba untuk melakukan metode yang berbeda apabila akan mengembangkan lebih jauh aspek strategi koping pada remaja pernikahan dini.

\section{Daftar Pustaka}

Alwisol. (2014). Psikologi kepribadian. Malang: UMM Press.

Ageng. (17 Januari, 2017). Angka pernikahan dini di Bandung Barat masih tinggi. Fokus Jabar. Diakses pada 15 Agustus, 2017, dari

http://fokusjabar.com/2017/01/17/angka-

pernikahan-dini-bandung-barat-masihtinggi/

Bungin, B. (2008). Analisis data penelitian kualitatif. Jakarta: Rajawali Pers.

Bruce, J. (2007). Child marriage in the context of the HIV epidemic. Brief Journal, 11(2), $1-4$.

Casmini. (2002). Pernikahan dini dalam perspektif psikologi dan agama. Jurnal Aplikasi Ilmu Agama, 3(1), 45-57.

Dariyo, A. (2004). Memahami psikologi perceraian dalam kehidupan keluarga. Jurnal Psikologi, 2(2), 94-100.

Desmita. (2005). Psikologi Perkembangan. Bandung: Rosda Karya.

Dewi, E., \& Basti. (2008). Konflik perkawinan dan model penyelesaian konflik pada pasangan suami isteri. Jurnal Psikologi, 2(1), 42-51.

Fadliyana, E. \& Larasati. (2009). Pernikahan usia dini dan permasalahannya. Jurnal Sari Pediatri, 11(2), 135-140.

Gilarso, T. (2003). Moral keluarga. Yogyakarta: Universitas Sanata Dharma.
Guritnaningsih, A. S., \& Lucia. M. R. (2009). Teknik penulisan laporan penelitian kualitatif. Jakarta: LPSP3 (Lembaga Pengembangan Sarana Pengukuran dan Pendidikan Psikologi) Fakultas Psikologi Universitas Indonesia.

Hurlock, E. B. (1994). Psikologi perkembangan, suatu pendekatan sepanjang rentang kehidupan. Jakarta: Erlangga.

Kartono, K. (2002). Psikologi wanita jilid 1: Mengenal gadis remaja dan wanita dewasa. Bandung: Mandar Maju.

Kementerian Kesehatan. (2013). Riset kesehatan dasar. Jakarta: Badan Penelitian dan Pengembangan Kesehatan.

Khairunnisa, D., \& Setiali. A. (2016). Tingkat stres pada remaja wanita yang menikah dini di Kecamatan Babakan Cikao Kabupaten Purwakarta. Jurnal Imu Keperawatan, 4(2), 67-76.

Landung, J., Ridwan, \& Dzulkifli. (2009). Studi kasus kebiasaan pernikahan dini pada masyarakat Kecamatan Sanggalani Kabupaten Tana Toraja. Jurnal MKMI, 5(4), 89-94.

Lazarus, R., \& Folkman. (1984). Stress, appraisal and coping. New York: Springer Publishing Company.

Nurdjanah, A., \& Asyanti, S. (2015). Permasalahan pada remaja yang menikah dini di Surakarta. Jurnal Keperawatan, 11(2), 54-65.

Papalia, D. E., Olds, S. W., \& Feldman, R. D. (2008). Human development: Psikologi perkembangan. Jakarta: Kencana.

Poerwandari, E. K. (1998). Pendekatan kualitatif untuk penelitian perilaku manusia. Jakarta: LPSP3 (Lembaga Pengembangan Sarana Pengukuran dan Pendidikan Psikologi) Fakultas Psikogi UI.

Raharjo, I. T., Puspitawati, H. \& Krisnatuti, D. (2015). Tekanan ekonomi, manajemen keuangan dan kesejahteraan pada keluarga muda. Jurnal Ilmu Keluarga dan Konsumen, 8(1), 38-48, ISSN: 1907 6037.

Rahman, A. A. (2016). Metode penelitian psikologi: Langkah cerdas dalam menyelesaikan skripsi. Bandung: Remaja Rosda Karya. 
Rice, F. P. (1990). The adolescent development, relationship \& culture (ed. 6). Boston: Ally \& Bacon.

Santrock, J. W. (2007). Remaja (ed. 11). Jakarta: Erlangga.

Sears, D. O., Freedman, J. L \& Peplau, L. A (1994). Psikologi sosial. Jakarta: Erlangga.

Sutanto, L. (2013). Kiat jitu menulis skripsi, tesis dan disertasi. Jakarta: Erlangga.

Tydar. (2012). Faktor serta dampak pernikahan dini di Desa Nglamuk, Kelurahan Legoksari, Kecamatan Tlogomulyo, Kabupaten Temanggung. Jurnal Keperawatan, 13(3), 72-83.
Ulfiah. (2016). Psikologi keluarga: Pemahaman hakikat keluarga dan penanganan problematika rumah tangga. Bogor: Ghalia Indonesia.

Undang - Undang Republik Indonesia Nomor 1 Pasal 1 Ayat 7 Tahun 1974: Perkawinan.

Undang - Undang Republik Indonesia Nomor 36 tahun 2009: Kesehatan.

Undang - Undang Republik Indonesia Nomor 12 tahun 1992: Perkembangan Penduduk dan Pembangunan Keluarga Sejahtera.

Yahya, Y. (2011). Psikologi perkembangan. Jakarta: Kencana. 
Psympathic, Jurnal Ilmiah Psikologi Juni 2018, Vol. 5, No. 1, Hal: 23-42 